\title{
Breastfeeding and aspects of the baby's oral health and its relationship with infant
}

\section{hospitalization and use of antibiotics}

\author{
Amamentação e aspectos da saúdle bucal do bebê e sua relação com a hospitalização infantil e uso \\ de antibióticos
}

Lactancia materna y aspectos de la salud bucal del bebé y su relación con la hospitalización infantil y el uso de antibióticos

Received: 03/23/2021 | Reviewed: 03/30/2021 | Accept: 04/03/2021 | Published: 04/13/2021

\author{
Gleice Tibauje Vicente Ramirez \\ ORCID: https://orcid.org/0000-0003-2050-6685 \\ Universidade Estadual Paulista, Brasil \\ E-mail: ramirez.tvgleice@gmail.com \\ Ana Cláudia Okamoto \\ ORCID: https://orcid.org/0000-0002-8594-9754 \\ Universidade Estadual Paulista, Brasil \\ E-mail: ana.okamoto@unesp.br \\ Fernando Yamamoto Chiba \\ ORCID: https://orcid.org/0000-0003-4406-405X \\ Universidade Estadual Paulista, Brasil \\ E-mail:fernando.chiba@unesp.br \\ Tânia Adas Saliba \\ ORCID: https://orcid.org/0000-0003-1327-2913 \\ Universidade Estadual Paulista, Brasil \\ E-mail: tania.saliba@unesp.br \\ Suzely Adas Saliba Moimaz \\ ORCID: https://orcid.org/0000-0002-4949-529X \\ Universidade Estadual Paulista, Brasil \\ E-mail: suzely.moimaz@unesp.br
}

\begin{abstract}
The present study aimed to verify the influence of breastfeeding on children's oral and systemic health, verifying children's hospitalization, use, indication and type of antibiotics used. This is a cross-sectional longitudinal study with a sample of 42 children at 30 months of age. The logistic regression test was used at a significance level of $5 \%$ for statistical analysis. Among the children, $64.28 \%$ had already been weaned before reaching 6 months of age; $11.90 \%$ had caries lesion. Simplified Oral Hygiene Index (OHI-S) was performed in 38 children, from which $92.10 \%$ had regular OHI-S and $07.90 \%$ had poor OHI-S. Of the 42 children, the indication for antibiotics use was $50 \%$ for pharyngitis, $28.83 \%$ for pneumonia, $08.33 \%$ for cold, $04.17 \%$ for sinusitis, $04.17 \%$ for bronchitis, $04.17 \%$ for stomatitis, $04.17 \%$ for virus and $04.17 \%$ for ocular cellulitis. In this study, there was no relationship between early weaning, oral health conditions, hospitalization and antibiotics use. Presence of caries in early childhood was found in $11.90 \%$ of children. All children presented unsatisfactory OHI-S and there was no relationship between this variable and the others. Much of the indication for the use of antibiotics was for the treatment of respiratory tract infections, with beta lactams being the most used.
\end{abstract}

Keywords: Breastfeeding; Oral health; Anti-bacterial agents; Hospitalization.

\section{Resumo}

O presente estudo teve como objetivo verificar a influência do aleitamento materno na saúde bucal e sistêmica de crianças, verificando a hospitalização infantil, o uso, a indicação e o tipo de antibióticos utilizados. Trata-se de um corte transversal de estudo longitudinal com amostra de 42 crianças aos 30 meses de idade. O teste de regressão logística foi utilizado com nível de significância de 5\% para análise estatística. Entre as crianças, 64,28\% já haviam sido desmamadas antes dos 6 meses de idade; 11,90\% tinham lesão de cárie. O Índice de Higiene Oral Simplificado (IHO-S) foi realizado em 38 crianças, das quais 92,10\% tinham IHO-S regular e 07,90\% tinham IHO-S ruim. Das 42 crianças, a indicação de uso de antibióticos foi de $50 \%$ para faringite, $28,83 \%$ para pneumonia, $08,33 \%$ para resfriado, $04,17 \%$ para sinusite, $04,17 \%$ para bronquite, $04,17 \%$ para estomatite, $04,17 \%$ para vírus e $04,17 \%$ para celulite ocular. Neste estudo, não houve relação entre desmame precoce, condições de saúde bucal, hospitalização e uso de antibióticos. A presença de cárie na primeira infância foi encontrada em 11,90\% das crianças. Todas as crianças apresentaram IHO-S insatisfatório e não houve relação entre essa variável e as demais. Grande parte da indicação de 
uso de antibióticos foi para o tratamento de infecções do trato respiratório, sendo os beta-lactâmicos os mais utilizados.

Palavras-chave: Aleitamento materno; Saúde bucal; Antibacterianos; Hospitalização.

\section{Resumen}

El presente estudio tuvo como objetivo verificar la influencia de la lactancia materna en la salud oral y sistémica de los niños, verificando la hospitalización, uso, indicación y tipo de antibióticos utilizados en los niños.. Este se trata de un estudio longitudinal transversal con una muestra de 42 niños a los 30 meses de edad.. Se utilizó la prueba de regresión logística con un nivel de significancia del 5\% para el análisis estadístico. Entre los niños, el 64,28\% ya había sido destetado antes de los 6 meses de edad; El 11,90\% presentaba lesiones por caries. El Índice de Higiene Oral Simplificado (IHO-S) se realizó en 38 niños, de los cuales el 92,10\% tenía IHO-S regular y el 07,90\% tenía IHOS deficiente. De los 42 niños, la indicación para el uso de antibióticos fue 50\% para faringitis, 28,83\% para neumonía, $08,33 \%$ para resfriado, $04,17 \%$ para sinusitis, $04,17 \%$ para bronquitis, $04,17 \%$ para estomatitis, $04,17 \%$ para virus y 04,17\% para celulitis ocular . En este estudio, no hubo relación entre el destete temprano, las condiciones de salud bucal, la hospitalización y el uso de antibióticos. Las caries de la primera infanciase encontró en el 11,90\% de los niños. Todos los niños tuvieron un IHO-S insatisfactorio y no hubo relación entre esta variable y las demás. Gran parte de la indicación del uso de antibióticos fue para el tratamiento de infecciones del tracto respiratorio, siendo los betalactámicos los más utilizados.

Palabras clave: Lactancia materna; Salud bucal; Antibacterianos; Hospitalización.

\section{Introduction}

It is known that during pregnancy the mother transfers antibodies or immunoglobulins, especially $\operatorname{IgG}$, via umbilical cord to the fetus and when the baby is born, this transfer is interrupted (Petrechen et al., 2015). In addition to this interruption in passive immunization, the baby's immune system is immature, as it has not yet undergone antigenic challenges, leaving it susceptible to a series of infections 1-2, with the need for another source of protection for the newborn (Petrechen et al., 2015). Breastfeeding (BF) provides the baby with a passive immunity transfer (Hanson et al., 1994), with unquestionable protective attributes associated with reducing the risk of neonatal infection (Andreas, Kampmann, \& Mehring Le-Doare, 2015; Petrechen et al., 2015). Breast milk contains large amounts of leukocytes, such as macrophages and neutrophils, lymphocytes, including T cells and natural killer cells, antibody producing B cells (Wold \& Adlerberth, 1998), lysozyme, lactoferrin, complement system components, bioactive peptides, oligosaccharides, lipids and bifidus factor, which inhibits colonization by gramnegative microorganisms (Succi, 1998).

Antibodies present in breast milk are a consequence of antigenic stimulation of the lymphoid tissue associated with the maternal mucosa and the bronchial tree (bronchomammary tract) (Goldman, 2000). These antibodies come from the infectious agents that the mother was exposed to during the perinatal period, as the baby is very likely to be exposed to the same pathogens (Andreas, Kampmann, \& Mehring Le-Doare, 2015). Therefore, breast milk contains antibodies specific for many enteric and respiratory pathogens, and it is in colostrum that immunoglobulins are present in particularly high concentrations, with secretory IgA being the class found in breast milk (Castellote et al., 2011). The presence of IgA represents the first line of defense of mucous membranes, offering protection against infections, preventing adhesion and invasion of microorganisms in tissues (Andreas, Kampmann, \& Mehring Le-Doare, 2015; Hanson et al., 1994; Hurley \& Theil, 2011; Petrechen et al., 2015; Wold \& Adlerberth, 1998). These immunoglobulins bind to potential pathogens and prevent their binding to the baby's gastrointestinal and respiratory mucous membranes (Jackson \& Nazar, 2006; Palmeira \& CarneiroSampaio, 2016).

Therefore, passive immunization through $\mathrm{BF}$ promotes neonatal protection against diarrhea caused by $V$. cholerae, enterotoxigenic E. coli and Campylobacter (Cabinian et al., 2016; Cruz, Gil, Cano, Caceres \& Pareja, 1988; Glass et al., 1983; Ruiz-Pallacios et al., 1990). Newborn babies have the intestinal microbiota with the largest number of bifidobacteria (Penders et al., 2006; Succi, 1998), especially for IgA content which, when covering the intestinal epithelium with specific antibodies, prevents the adhesion of enteric pathogens, making the installation of the disease (World Health Organization, 1988). 
Studies show that the practice of breastfeeding promotes protection against respiratory morbidity (Boccolini, Carvalho, Oliveira, \& Boccolini, 2011; César, Victora, Barros, Santos, \& Flores, 1999; Oddy et al., 2003). The increased prevalence of exclusive breastfeeding (EBF) in the first six months of the baby's life and the increased breastfeeding rate in the first year of life may reduce the risk of hospitalizations for pneumonia (Boccolini, Carvalho, Oliveira, \& Boccolini, 2011), as it decreases the severity of disease episodes (César, Victora, Barros, Santos, \& Flores, 1999). Early weaning accompanied by the introduction of milk formula is a significant risk factor for upper respiratory tract infections, such as acute otitis media and tonsillitis (Kuiper et al., 2007), wheezing of lower respiratory tract diseases (Payne \& Quigley, 2017) and, when more aggravated, the consequent hospitalization (Oddy et al., 2003).

Additionally, the mouth acts as a reservoir for a variety of microorganisms, including those that cause intestinal and respiratory infections, which are the main causes of hospitalization and antibiotics use. Thus, factors that modify oral ecosystems, such as hygiene, type of food and the occurrence of caries and/or periodontal disease, may predispose the baby to these diseases (Awano et al., 2008; Dewhirst et al., 2010).

In short, it is observed that the practice of breastfeeding generates benefits for the mother-child binomial, reduces infant mortality rates, has economic, nutritional and immunological advantages over formula consumption, in addition to being ecological (Kuiper et al., 2007; Marques et al., 2020; Silva et al., 2020; Sousa et al., 2021). Because breast milk is a means of acquiring numerous short and long-term protective factors in the child's life, the present study aimed to verify the influence of breastfeeding on children's oral and systemic health, verifying children's hospitalization, use, indication and type of antibiotics used.

\section{Methodology}

Study Design:

This is a cross-section of a longitudinal study with a sample of 42 children at 30 months of age.

The logistic regression statistical analysis was used, at a significance level of $5 \%$.

Description of the longitudinal study:

In the month of January to December of the year 2016, the project started with the visit of the team of researchers in all 18 Family Health Units in a municipality in the interior of the state of São Paulo, where only Community Health Agents make visits households.

The pregnant women were selected from the 18 Family Health Units and were in the last trimester of pregnancy. The approach was performed while waiting for prenatal care and consultation with the gynecologist / obstetrician. At that time, the pregnant women answered a questionnaire about the expectation of delivery and the intention and expectation of breastfeeding, in addition to filling out the registration data for home visits that would occur at 6 and 30 months of age.

After the interview, pamphlets were distributed on the encouragement of breastfeeding and installation of healthy oral and food habits for mother and baby, in addition to the reproduction of a motivational video with the same content. At 6 months of age, the families were visited at home to collect data on eating practices and obtain anthropometric data.

The logistic regression statistical analysis was used, at a significance level of $5 \%$.

The sample calculation was based on the variable rate of exclusive breastfeeding at six months of age in the studied population (Rocha, Garbin, Garbin, Saliba, \& Moimaz, 2013). Calculation for sample size (finite population):

$$
\mathrm{n}=\frac{\mathrm{Z}^{2} \times \mathrm{P} \times \mathrm{Q} \times \mathrm{N}}{\mathrm{e}^{2} \times(\mathrm{N}-1)+\mathrm{Z}^{2} \times \mathrm{P} \times \mathrm{Q}}
$$


Subtitle:

Z - 95\% confidence interval - 1.96

$\mathrm{P}$ - Rate of exclusive breastfeeding expected at six months of age - $10 \%$

Q - Percentage of babies not exclusively breastfed at six months - 90\%

$\mathrm{N}$ - Total population of pregnant women in the study period - 725

e - Absolute sampling error - $5 \%$

Result: 116 pregnant women with a $30 \%$ increase, rounded up to 150 pregnant women.

Sample loss:

The initial sample consisted of 150 mother-child pairs, during the visit and follow-up phase at 6 months of the child's life, there was a loss of $50.67 \%$ of the sample, totaling 74 mother-child pairs. At 30 months of age of the child, the period of the current study, there was a loss of $72 \%$ of the initial sample, corresponding to 42 mother-child pairs.

The loss of the sample occurred due to changes in address and telephone numbers and cell phones by the families belonging to the study, during the time interval from one phase to another of the research.

Characteristics of the research site:

The research was carried out in a municipality in the state of São Paulo, Brazil, a regional reference for health care, with a population, according to the last sense in 2010, of 181579 inhabitants, and estimated for the year 2019 of 197016 inhabitants, with GDP per capita of $\mathrm{R} \$ 35,769.43$. Average wage of formal workers of 2.5 minimum wages, with an average infant mortality rate of 11.02 per 1000 live births. The municipality in question has a total of 18 Family Health Units, which offer services in Primary Health Care to the population (Instituto Brasileiro de Geografia e Estatística, 2010).

Data Collection:

A training for interviewer and annotator was conducted for two weeks for clarifying project objectives and application methods and completing the data collection instrument. The training aimed at standardizing procedures for data collection and the guidelines that were to be performed during home visits.

At 30 months of age, the families were visited at home to conduct interviews on the aspects of breastfeeding, early weaning, antibiotics use and indication, and hospitalization, and a clinical oral examination was performed on the children to verify the Simplified Oral Hygiene Index (OHI-S) and the presence of caries according to the World Health Organization (WHO) criteria (Brasil, 2001) and $05 \mathrm{ml}$ of saliva was collected from the oral floor using sterile disposable pipettes in the morning.

After collection, the material was transported in polyethylene microtubes and seeded in Petri dishes in duplicate, containing Sabouraud dextrose with chloromphenicol (Echeverría, Durante, Arechavala, \& Negroni, 2002) and incubated at $37^{\circ} \mathrm{C}$ for 48 hours to count the colonies formed.

It was conducted in $38 \mathrm{OHI}-\mathrm{S}$ children, the rest of the children did not agree with the procedure, even in several attempts on different days.

The data was recorded in a clinical form developed for this study.

This work respected the ethical precepts for research with human beings, established in the Declaration of Helsinki and in Resolution No. 466/12 (Brasil, 2012), with approval by the Ethics and Research Committee on Human Beings (CAAE 15049319.0.0000.5420).

The authors have no conflicts of interest. 


\section{Results}

Table 1 - Numerical distribution, percentage and logistic regression of the variables: education and occupation of the mother and family income with the variable early weaning. Brazil, 2020.

\begin{tabular}{|c|c|c|c|c|c|}
\hline Variables & $\mathrm{n}$ & $\%$ & $<0.05$ & Odds-ratio & Confidence Interval \\
\hline \multicolumn{6}{|c|}{ Education level in years of study } \\
\hline Up to 07 & 09 & 21.43 & 0.70 & 1.75 & $0.09-30.83$ \\
\hline $08-10$ & 11 & 26.19 & 0.92 & 0.87 & $0.05-12.97$ \\
\hline 11 & 22 & 52.38 & 0.77 & 0.68 & $0.05-08.96$ \\
\hline Total & 42 & 100.00 & & & \\
\hline \multicolumn{6}{|l|}{ Occupation } \\
\hline Works outside the home & 16 & 38.10 & 0.49 & 1.94 & $0.09-30.83$ \\
\hline Works at home & 03 & 07.14 & 0.26 & 2.33 & $0.05-12.97$ \\
\hline "Home" occupation & 23 & 54.77 & 0.47 & 0.38 & $0.05-08.96$ \\
\hline Total & 42 & 100.00 & & & \\
\hline \multicolumn{6}{|c|}{ Family income in minimum wage } \\
\hline Up to 1 & 13 & 30.95 & 0.36 & 2.50 & $0.34-18.03$ \\
\hline$>1-2$ & 19 & 45.24 & 0.97 & 1.03 & $0.17-05.94$ \\
\hline$>2-4$ & 10 & 23.81 & 0.77 & 1.50 & $0.08-25.39$ \\
\hline Total & 42 & 100.00 & & & \\
\hline
\end{tabular}

Source: Authors (2020).

According to socio-educational data (Table 1), most mothers have completed high school, reported to have home occupations and declared the family income to be up to two minimum wages. There was no relationship between these variables and the variable early weaning.

The interview data revealed that $27(64.28 \%)$ of the mothers had stopped breastfeeding before the baby was six months old and, according to the statistical analysis, there was no relationship between early weaning and the variables: hospital stay, use of antibiotics, unsatisfactory OHI-S, presence of caries lesions and presence of Candida colonies in the children's oral cavity (Table 2).

Table 2 - Logistic regression of the variables: hospitalization of the child, use of antibiotics, unsatisfactory OHI-S, presence of caries and Candida with the variable early weaning. Brazil, 2020.

\begin{tabular}{lcrr}
\hline Variables & $<0.05$ & Odds-ratio & Confidence Interval \\
\hline Hospitalization & 0.34 & 0.44 & $0.07-02.45$ \\
Use of Antibiotics & 0.78 & 1.20 & $0.33-04.32$ \\
OHI-S & 0.97 & 0.96 & $0.07-11.67$ \\
Presence of caries & 0.06 & 9.45 & $0.94-94.48$ \\
Presence of Candida & 0.26 & 2.18 & $0.56-08.51$ \\
\hline
\end{tabular}


Was conducted in 38 children OHI-S (the rest of the children did not agree with the procedure, even in several attempts on different days), of these children, 35 (92.10\%) had regular OHI-S and 03 (07.90\%) had poor OHI-S and there was no unsatisfactory relation between hospital admission, antibiotics use and the presence of caries lesions in the oral cavity of children (Table 3).

Table 3 - Logistic regression of the variables: hospitalization of the child, use of antibiotics and presence of caries with the variable OHI-S. Brazil, 2020.

\begin{tabular}{lccr}
\hline Variables & $<0.05$ & Odds-ratio & Confidence Interval \\
\hline Hospitalization & 0.91 & 0.00 & $0.00-\infty$ \\
Use of Antibiotics & 0.82 & 0.75 & $0.06-09.08$ \\
Presence of caries & 0.31 & 0.25 & $0.01-03.53$ \\
\hline
\end{tabular}

Source: Authors (2020).

From the 42 children examined, $05(11.90 \%)$ had caries lesions and there was no relationship between caries and hospital admission, antibiotics use and unsatisfactory OHI-S (Table 4).

Table 4 - Logistic regression of the variables: hospitalization of the child, use of antibiotics and OHI-S with the variable presence of caries. Brazil, 2020.

\begin{tabular}{lccr}
\hline Variables & $<0.05$ & Odds-ratio & Confidence Interval \\
\hline Hospitalization & 0.93 & 1.10 & $0.10-11.30$ \\
Use of Antibiotics & 0.89 & 0.87 & $0.13-05.87$ \\
OHI-S & 0.31 & 0.25 & $0.01-03.53$ \\
\hline
\end{tabular}

Source: Authors (2020).

This was collected from 39 children $(92.86 \%)$, with no cooperation or agreement from the others. After saliva culture, $51.28 \%(\mathrm{n}=20)$ of the growing yeast samples of the genus Candida were registered and had no relationship with the growth of the microorganism with the use of antibiotics and hospitalization (Table 5).

Table 5 - Logistic regression of the variables: hospitalization of children and use of antibiotics with variable presence of Candida. Brazil, 2020.

\begin{tabular}{lccc}
\hline Variables & $<0.05$ & Odds-ratio & Confidence Interval \\
\hline Hospitalization & 0.29 & 2.28 & $0.48-10.88$ \\
Use of Antibiotics & 0.62 & 0.72 & $0.21-02.57$ \\
\hline
\end{tabular}

Source: Authors (2020).

The children's medical history, reported by the mothers, shows that by the age of 30 months, 09 children, out of a total of 42 , had already been hospitalized and the causes reported by the mothers were: $55.56 \%(\mathrm{n}=5)$ due to respiratory tract infection, being 04 cases of pneumonia and 01 of pertussis. And the other cases of hospitalization were: 01 case of hernia (11.11\%), 01 case of virosis (11.11\%), 01 case of seizure (11.11\%) and 01 case of drug side effect (11.11\%). In this period, 24 $(57.14 \%)$ out of a total of 42 children had already undergone antibiotic therapy at least once (Figure 1). 
Figure 1 - Percentage distribution, according to the reason for indicating antibiotics use, in children aged 30 months. Brazil, 2020.

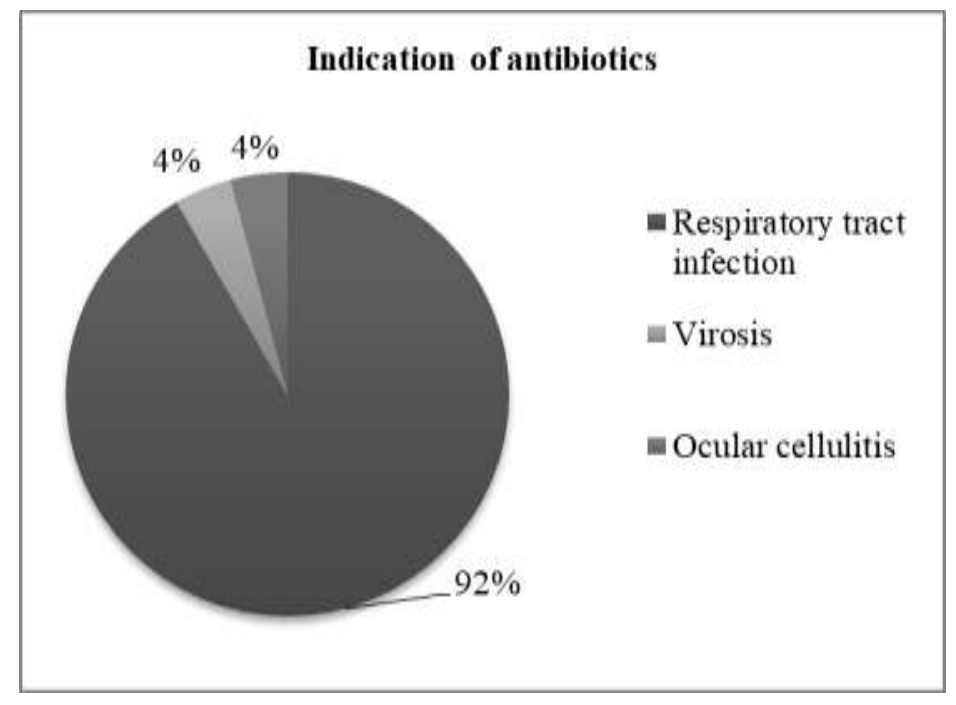

Source: Authors (2020).

Among the respiratory tract infections that required antibiotics use, there are: 12 cases of pharyngitis (50\%), 05 cases of pneumonia (20.83\%), 02 cases of cold $(08.33 \%), 01$ case of sinusitis $(04.17 \%), 01$ case of bronchitis $(04.17 \%)$ and 01 case of stomatitis $(04.17 \%)$. There was still $01(04.17 \%)$ case of viral infection and $01(04.17 \%)$ of ocular cellulitis (Figure 1). The most antibiotic used for the children were Amoxicillin (Figure 2).

Figure 2 - Percentage distribution, according to the type of antibiotics used in children aged 30 months. Brazil, 2020.

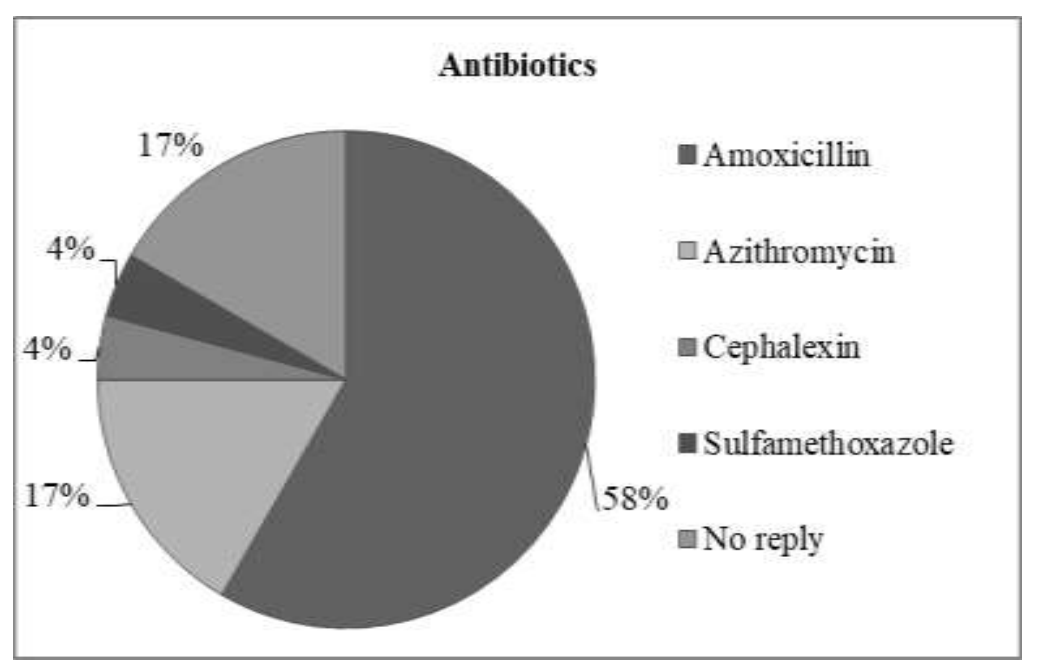

Source: Authors (2020).

\section{Discussion}

Breast milk is full of nutrients, and the practice of breastfeeding can be interpreted as a natural and instinctive act, and it is believed that individual, family and social factors can interfere and compromise this practice (Rocha, Garbin, Garbin, \& Moimaz, 2010). Table 1 shows that mothers have a low level of education and most have family income less than two minimum wages, studies suggest that socio-demographic characteristics, such as low level education, age and mother's occupation and family income can influence the failure of breastfeeding (Cavalcanti, Silva, \& Nascimento, 2021; Rocha, Garbin, 
Garbin, \& Moimaz, 2010; Sousa Siqueira, Stabnow Santos, Gomes Nogueira Ferreira, Fernandes Oliveira, Costa Dutra, \& Santos Neto, 2020), however, this fact was not associated to early weaning in this study. There is a biological likelihood for the long-term protective effects of breastfeeding and the consequences of BF support the idea that what is nourished to childhood can later influence lung function (Sears et al., 2002; Wright, Holberg, Taussig, \& Martinez, 2001). In this sense, there are reports that the components of human milk influence the immune system years after breastfeeding has ceased (Hanson, 1999). And it is possible that these effects offer protection and consequently reduce the need for antibiotics use (Parker, O'Sullivan, Shea, Regan, \& Freedman, 2004), as shorter breastfeeding compromises children's health and thus leads to future treatment with antibiotics (Krenz-Niedbała, Kościński, Puch, Zelent, \& Bręborowicz, 2015).

In the present study, most mothers interrupted EBF before the baby was six months old, which can lead to losses for the correct development of the child in this period (Wright, Holberg, Taussig, \& Martinez, 2001). It is known that the causes of early weaning are multifactorial (Cavalcanti, Silva, \& Nascimento, 2021; Rocha, Garbin, Garbin, \& Moimaz, 2010; Sousa Siqueira, Stabnow Santos, Gomes Nogueira Ferreira, Fernandes Oliveira, Costa Dutra, \& Santos Neto, 2020) and that many women yearn to breastfeed, however, the practice differs from the expected and the interruption of EBF occurs and, often, even in the first month of the baby's life (Moimaz, Amaral, Miotto, Costa, \& Garbin, 2016; Mucha, Lohmann, Laste, \& Marchese, 2020; Rocha, Garbin, Garbin, Saliba, \& Moimaz, 2013). Thus, it is essential to have health professionals monitor these families in order to assist the achievement and success of BF (Wright, Holberg, Taussig, \& Martinez, 2001; Mucha, Lohmann, Laste, \& Marchese, 2020). The prevalence of eating habits, such as BF, and oral health care generates benefits for the whole organism, both in childhood and in adulthood. The early establishment of such practices is of paramount importance and should be encouraged and worked on frequently with the entire population to prevent various diseases and maintain health as a whole (Moimaz, Amaral, Miotto, Costa, \& Garbin, 2016; Rocha, Garbin, Garbin, Saliba, \& Moimaz, 2013).

On the other hand, although the causes of weaning are multifactorial (Cavalcanti, Silva, \& Nascimento, 2021; Rocha, Garbin, Garbin, \& Moimaz, 2010; Sousa Siqueira, Stabnow Santos, Gomes Nogueira Ferreira, Fernandes Oliveira, Costa Dutra, \& Santos Neto, 2020), the relationship between the interruption of breastfeeding and the introduction of inappropriate eating habits is known. The early introduction of sweetened substances in the child's diet, in addition to interfering with breastfeeding habits, can lead to weaning and are related to early colonization by Streptococcus mutans, the main cariogenic bacterium that lowers $\mathrm{pH}$, favoring colonization by Candida, which in turn can be used as an indicative factor for low immunity when it presents a significant increase (Mattos-Graner, Zelante, Line, \& Mayer, 1998; Rocha, Garbin, Garbin, Saliba, \& Moimaz, 2013).

It is also known that microorganisms present in the mouth can be aspirated and cause pneumonia (Awano et al., 2008; Payne \& Quigley, 2017). In the present study, there was no relationship between the presence of caries and regular or poor OHI-S and the presence of Candida with the child's hospitalization. Several studies show the relationship between oral and systemic health in adults (Awano et al., 2008; Dewhirst et al., 2010), but, in infants, studies are more scarce, so the verification of the association between the presence of caries in childhood, OHI-S and child hospitalization studied in this work is interesting. The presence of caries and visible biofilm can be indicative of lack or neglect of oral health, facilitating the occurrence of secondary and/or diseases associated with the disease, or still, the lack of knowledge and/or guidance of caregivers. Just as the oral microbiome interferes with a person's systemic health (Awano et al., 2008; Dewhirst et al., 2010), hospitalization of an individual can contribute to neglect oral health care, with an increase and accumulation of biofilm, usually due to poor brushing, causing an aggravation of oral health and consequently general health (Carvalho Baptista, Martinho, Nascimento, Rocha Santos, Prado, \& Valera, 2018; Gaetti-Jardim, Setti, Cheade, \& Mendonça, 2013; Zuanazzi et al., 2010).

There is protection provided by resistance factors in breast milk against colonization of the genus Candida in the oral cavities of breastfed infants, which suggests that breastfeeding is a protective factor against oral colonization in the baby by 
fungi of the genus Candida. The importance of considering this additional protection of breastfeeding for the health of infants is that, in addition to restricting the occurrence of oral candidiasis in an individual who has not yet reached their full immunological potential, it will also prevent it from entering deeper places in the human body (Zöllner \& Jorge, 2003).

The presence of yeasts such as the genus Candida, especially C. albicans, in the oral microbiome is part of the collection of microorganisms that the mouth houses and only presents danger to the organism when its virulence factor is greater than the host's defense power, that is, when there is an imbalance of microorganisms due to a failure in the immune system or a decrease in other microorganisms that compete for the environment, generating the emergence of opportunistic fungal infections (Bertolini \& Dongari-Bagtzoglou, 2019). In this study, despite the majority of children's saliva samples showing Candida, there was no relationship with the fact that the children were hospitalized or why they used antibiotics. Although the majority used antibiotics, possibly, the presence of Candida is due to more ecological interactions than to predisposing factors of the host. It is known that the continuous use of antibiotics can favor the increasing growth of fungi in the oral cavity, precisely because it unbalances the environment, quantitatively and qualitatively decreasing the bacteria. Like any microorganism in the mouth, yeasts can be aspirated and generate even greater systemic problems such as pneumonia (Bertolini \& Dongari-Bagtzoglou, 2019; Zöllner \& Jorge, 2003).

It is known that EBF up to six months of age, as recommended by the WHO, generates a persistent protective effect for respiratory tract infections, being associated with the reduced risk for these infections in children of preschool age (Tromp et al., 2017). Secretory IgA from human milk has a protective action against infections of the gastrointestinal and respiratory tract (Andreas, Kampmann, \& Mehring Le-Doare, 2015; Hanson et al., 1994; Petrechen et al., 2015; Wold \& Adlerberth, 1998) and breastfeeding has long-term protective effects on respiratory infections and such effects may become apparent as children become older (Cabinian et al., 2016; Hanson et al., 1994; Succi, 1998; Wold \& Adlerberth, 1998; Yamakawa et al., 2015). Children who were breastfed have specific microbial patterns in the nasopharynx, associated with decreased susceptibility to respiratory infections (mild) and wheezing in childhood and throughout life (Biesbroek et al., 2014).

In the present study, the number of children hospitalized was low compared to the number of children who were treated with antibiotics $(57.14 \%)$ and there was no relationship between these variables with weaning, but $57.14 \%$ had respiratory problems. More than half of the hospitalizations was due to diseases of the lower respiratory tract, such as pneumonia. Studies show that EBF has a protective factor that can reduce hospital admissions for pneumonia (César, Victora, Barros, Santos, \& Flores, 1999; Kuiper et al., 2007; Tromp et al., 2017). It is known that childhood pneumonia can be associated with several factors, such as secondhand smoke, chemical substances, closed environments, family agglomeration, acquired immunodeficiency virus (HIV), low birth weight and malnutrition (Ngocho, Jonge, Minja, Mahande, Msuya, \& Mambaga, 2019; Tazinya, Halle-Ekane, Mbuagbaw, Abanda, Atashili, \& Obama, 2018), as well as early weaning or nonbreastfeeding (Tromp et al., 2017). Therefore, during the lactation period, as inappropriate baby feeding practices, they may have a deficiency of nutrients, which assists in the development of the disease and consequent hospitalization (Caetano, Ortiz, Silva, Souza, \& Sami, 2010; César, Victora, Barros, Santos \& Flores, 1999).

The treatment of respiratory tract infections depends on its etiology, and there are respiratory infections of viral, such as colds, fungal and bacterial origin. Often, treatment is started empirically, with the prescription of antimicrobials (Cabral et al., 2016; Tyrstrup, Melander, Heidin, \& Mölstad, 2017). In this work, most of the antibiotics prescriptions and hospitalizations were for the treatment of respiratory tract infection, and in some cases prescribed for diseases of non-bacterial origin. Antibiotics are still excessively and inadequately prescribed for viral infections of the respiratory tract. Generally the patient - or parents, when the patient is a child - exerts pressure for wanting the antibiotics and the physician ends up giving in. There are also other factors, such as the unenforceable rapid and accurate laboratory tests that differentiate bacterial infections from viral, the physician's difficulty in identifying patients with high risk of bacterial complications and those who 
practice defensive medicine (Kianmehr, Sabounchi, Seyedzadeh, Sabounchi, \& Cosler, 2019). In several countries, health agencies have been working to raise awareness of the use of antibiotics as a way to prevent the increase in resistance of microorganisms to antimicrobials (Cabral et al., 2016; Kianmehr, Sabounchi, Seyedzadeh, Sabounchi, \& Cosler, 2019; Tyrstrup, Melander, Heidin, \& Mölstad, 2017; World Health Organization, 2018).

In this study, it was found that the most used antibiotics was amoxicillin, as reported by the mothers, followed by macrolides. In most of these cases, usually beta lactams are the first choice due to their broad spectrum. Pneumococci from the respiratory tract have known sensitivity to this antimicrobial and the medicine has a more affordable price to the population (Mendes et al., 2003). Macrolides are reserved for cases of patient's allergy to penicillin and in cases of antimicrobial resistance, therefore, they are used as a second choice (ALAT Work Group, 2004). Cephalosporins were also used by the children in the study, but to a lesser extent. They are generally used in cases of more serious infections, in which the firstchoice antibiotics did not have the expected effect (Katsube, Saisho, Shimada, \& Furuie, 2019).

Despite the non-association of the various diseases studied in this study with early weaning, it is known that early interruption of BF can potentially contribute to the emergence of dental caries in early childhood and diseases caused by Candida and its complications, in addition to diseases that can affect the respiratory tract and the consequent use of antibiotics and the child's hospitalization (Awano et al., 2008; Bertolini \& Dongari-Bagtzoglou, 2019; Carvalho Baptista, Martinho, Nascimento, Rocha Santos, Prado, \& Valera, 2018; Dewhirst et al., 2010; Mattos-Graner, Zelante, Line, \& Mayer, 1998; Tromp et al., 2017; Zöllner \& Jorge, 2003). Therefore, breastfeeding practices should be promoted, as well as the monitoring of puerperal women by health professionals, in order to provide and maintain the well-being of the mother-child binomial.

\section{Conclusion}

In this study, it was found that most of the children had early weaning, all of them had unsatisfactory OHI-S, and some had caries in early childhood. Although few children were hospitalized, the majority used antibiotics, usually for the treatment of respiratory infection, and the most used antibiotics was a beta lactam (amoxicillin). There was no relationship between early weaning and oral health and/or hospitalization and use of antibiotics.

\section{Acknowledgments}

This work was carried out with the support of the Coordination for the Improvement of Higher Education Personnel (CAPES) Financing Code 001.

\section{References}

ALAT Work Group (2004). Update to the Latin American Thoracic Society (ALAT) Recommendations on Community-Acquired Pneumonia. Archivos de Bronconeumología, 40(8), 364-374. https://doi.org/10.1016/S1579-2129(06)60322-4

Andreas, N. J., Kampmann, B., \& Mehring Le-Doare, K. (2015). Human breast milk: a review on its composition and bioactivity. Early Human Development, 91(11), 629-635. https://doi.org/10.1016/j.earlhumdev.2015.08.013

Awano, S., Ansai, T., Takata, Y, Soh, I, Akifusa, S., Hamasaki, T., Yoshida, A., Sonoki, K., Fujisawa, K., \& Takehara, T. (2008). Oral health and mortality risk from pneumonia in the elderly. Journal of Dental Research, 87(4), 334-339. https://doi.org/10.1177/154405910808700418

Bertolini, M., \& Dongari-Bagtzoglou, A. (2019). The relationship of candida albicans with the oral bacterial microbiome in health and disease. In G. N. Belibasakis, G. Hajishengallis, N. Bostanci, \& M. A. Curtis (Eds.), Oral mucosal immunity and microbiome (pp. 69-78). Cham: Springer. https://doi.org/10.1007/978-3-030-28524-1_6

Biesbroek, G., Bosch, A. A. T. M., Wang, X., Keijser, B. J. K., Veenhoven, R. H., Sanders, E. A. M., \& Bogaert, D. (2014). The impact of breastfe eding on nasopharyngeal microbial communities in infants. American Journal of Respiratory and Critical Care Medicine, 190(3), 298-308. https://doi.org/10.1164/rccm.201401-00730C

Boccolini, C. S., Carvalho, M. L., Oliveira, M. I. C., \& Boccolini, P. M. (2011). Breastfeeding can prevent hospitalization for pneumonia among children under 1 year old. Jornal de Pediatria, 87(5), 399-404. https://doi.org/10.2223/JPED.2136 
Brasil (2001). Projeto SB2000: condições de saúde bucal da população brasileira no ano 2000. http://bvsms.saude.gov.br/bvs/publicacoes/condSB_man_exam.pdf

Brasil (2012). Resolução n. 466, de 12 de dezembro de 2012. Aprova diretrizes e normas regulamentadoras de pesquisas envolvendo seres humanos. https://bvsms.saude.gov.br/bvs/saudelegis/cns/2013/res0466_12_12_2012.html

Cabinian, A., Sinsimer, D., Tang, M., Zumba, O., Mehta, H., Toma, A., Sant'Angelo, D., Laouar, Y., \& Laouar, A. (2016). Transfer of maternal immune cells by breastfeeding: maternal cytotoxic T Lymphocytes present in breast milk localize in the peyer's patches of the nursed infant. PLoS One, 11 , e 0156762. https://doi.org/10.1371/journal.pone.0156762

Cabral, C., Ingram, J., Lucas, P. J., Redmond, N. M., Kai, J., Hay, A. D., \& Horwood, J. (2016). Influence of clinical communication on parents' antibiotic expectations for children with respiratory tract infections. Annals of Family Medicine, 14(2), 141-147. https://doi.org/10.1370/afm.1892

Caetano, M. C., Ortiz, T. T., Silva, S. G., Souza, F. I., \& Sarni, R. O. (2010). Complementary feeding: inappropriate practices in infants. Jornal de Pediatria, 86(3), 196-201. https://doi.org/10.1590/S0021-75572010000300006

Carvalho Baptista, I. M., Martinho, F. C., Nascimento, G. G., Rocha Santos, C. E., Prado, R., \& Valera, M. C. (2018). Colonization of oropharynx and lower respiratory tract in critical patients: risk of ventilator-associated pneumonia. Archives of Oral Biology, 85, 64-69. https://doi.org/10.1016/j.archoralbio.2017.09.029

Castellote, C., Casillas, R., Ramírez-Santana, C., Pérez-Cano, F. J., Castell, M., Moretones, M. G., López-Sabater, M. C., \& Franch, A. (2011). Premature delivery influences the immunological composition of colostrum and transitional and mature human milk. The Journal of Nutrition, 141(6), 1181-1187. https://doi.org/10.3945/jn.110.133652

Cavalcanti, N. B., Silva, A. C. M. da, \& Nascimento, J. W. A. do (2021). Fatores associados ao desmame precoce no Brasil: uma revisão integrativa. Pesquisa, Sociedade e Desenvolvimento , 10 (1), e58010111630. https://doi.org/10.33448/rsd-v10i1.11630

César, J. A., Victora, C. G., Barros, F. C., Santos, I. S., \& Flores, J. A. (1999). Impact of breast feeding on admission for pneumonia during postneonatal period in Brazil: nested case-control study. BMJ, 318, 1316-1320. https://doi.org/10.1136/bmj.318.7194.1316

Cruz, J. R., Gil, L., Cano, F., Caceres, P., \& Pareja, G. (1988). Breast milk anti-Escherichia coli heat-labile toxin IgA antibodies protect against toxin-induced infantile diarrhea. Acta Paediatrica Scandinavica, 77(5), 658-662. https://doi:10.1111/j.1651-2227.1988.tb10726.x

Dewhirst, F. E., Chen, T., Izard, J., Paster, B. J., Tanner, A. C., Yu, W. H., Lakshmanan, A., \& Wade, W. G. (2010). The human oral microbiome. Journal of Bacteriology, 192, 5002-5017. https://doi.org/10.1128/JB.00542-10

Echeverría, A., Durante, A. G., Arechavala, A., \& Negroni, R. (2002). Estudio comparativo de dos medios de cultivo para la de tección de la actividad fosfolipasa en cepas de Candida albicans y Cryptococcus neoformans. Revista Iberoamericana de Micología, 19: 95-98.

Gaetti-Jardim, E., Setti, J. S., Cheade, M. F. M., \& Mendonça, J. C. G. (2013). Atenção odontológica a pacientes hospitalizados: revisão da literatura e proposta de protocolo de higiene oral. Revista de Atenção à Saúde, 11(35), 31-36. https://doi.org/10.13037/rbcs.vol11n35.1769

Glass, R. I., Svennerholm, A. M., Stoll, B. J., Khan, M. R., Hossain, K. M., Huq, M. I., \& Holmgren, J. (1983). Protection against cholera in breast-fed children by antibodies in breast milk. The New England Journal of Medicine, 308(23), 1389-1392. https://doi.org/10.1056/NEJM198306093082304

Goldman, A. S. (2000). Modulation of the gastrointestinal tract of infants by human milk: interfaces and interactions: an evolutionary perspective. The Journal of Nutrition, 130(2), 426S-431S. https://doi.org/10.1093/jn/130.2.426S

Hanson, L. A. (1999). Human milk and host defence: immediate and long-term effects. Acta Paediatrica, 88(430), 42-46. https://doi.org/10.1111/j.16512227.1999.tb01299.x

Hanson, L. A., Hahn-Zoric, M., Berndes, M., Ashraf, R., Herias, V., Jalil, F., Bhutta, T. I., Laeeq, A., \& Mattsby-Baltzer, I. (1994). Breast feeding: overview and breast milk immunology. Pediatrics International, 36(5), 557-561. https://doi.org/10.1111/j.1442-200x.1994.tb03246.x

Hurley, W. L., \& Theil, P. K. (2011). Perspectives on immunoglobulins in colostrum and milk. Nutrients, 3(4), 442-474. https://doi.org/10.3390/nu3040442

Instituto Brasileiro de Geografia e Estatística (2010). Brasil / São Paulo / Araçatuba. https://cidades.ibge.gov.br/brasil/sp/aracatuba/panorama

Jackson, K. M., \& Nazar, A. M. (2006). Breastfeeding, the immune response, and long-term health. The Journal of the American Osteopathic Association, 106(4), 203-207.

Katsube, T., Saisho, Y., Shimada, J., \& Furuie, H. (2019). Intrapulmonary pharmacokinetics of cefiderocol, a novel siderophore cephalosporin, in healthy adult subjects. Journal of Antimicrobial Chemotherapy, 74(7), 1971-1974. https://doi.org/10.1093/jac/dkz123

Kianmehr, H., Sabounchi, N. S., Seyedzadeh Sabounchi, S., \& Cosler, L. E. (2019). Patient expectation trends on receiving antibiotic prescriptions for respiratory tract infections: a systematic review and meta-regression analysis. International Journal of Clinical Practice, 73(7), e13360. https://doi.org/10.1111/ijcp.13360

Krenz-Niedbała, M., Kościński, K., Puch, E. A., Zelent, A., \& Bręborowicz, A. (2015). Is the relationship between breastfeeding and childhood risk of asthma and obesity mediated by infant antibiotic treatment? Breastfeeding Medicine, 10(6), 326-333. https://doi.org/10.1089/bfm.2014.0173

Kuiper, S., Muris, J. W., Dompeling, E., Kester, A. D., Wesseling, G., Knottnerus, J. A., \& van Schayck, C. P. (2007). Interactive effect of family history and environmental factors on respiratory tract-related morbidity in infancy. Health Care Education, Delivery, and Quality, 120(2), 388-395. https://doi.org/10.1016/j.jaci.2007.03.038 
Marques, V. G. P. da S., Silva, M. P. B., Silva, P. I. de O., Alves, R. S. S., Jesus, G. de L. S. de, Sousa, A. B. de, Silva , A. B. F. da, Sousa, C. da S., Porto, M. de J., Soares, I. L., Bandeira, J. M. A., Silva, M. H. da, Fagundes, G. R. S., Oliveira, J. R. A., Carneiro, G. F. da C., Rocha, F. da S., Ferreira Júnior, S. M. da S., Torres, B. V. dos S., Havenstrin, V. C. de L., Silva, W. B. da, Lima, M. S., Carvalho, G. da S., Lima, R. de S., Pereira, L. O. R., Oliveira, B. de L., Silva, E. R. da, Silva, E. de J., Nascimento, A. M. V. do, Meneses, K. A., Brito, V. A., Silva, A. M. N. dos S., Sousa, F. L. L. de, Gomes, T. B., Paiva, M. T. G., Silva , A. B. A. da, Silva, L. I. de L. P., \& Vale, J. R. L. do. (2020). Breastfeeding: importance and benefits of breastfeeding. Research, Society and Development, 9(10), e2299108405. https://doi.org/10.33448/rsd-v9i10.8405

Mattos-Graner, R. O., Zelante, F., Line, R. C., \& Mayer, M. P. (1998). Association between caries prevalence and clinical, microbiological and dietary variables in 1.0 to 2.5-year-old Brazilian children. Caries Research, 32(5), 319-323. https://doi.org/10.1159/000016466

Mendes, C., Hsiung, A., Dencer, C., Felmingham, D., Rossi, F., Segura, A. J. A., Zoccoli, C. M., Sader, H., \& Mimica, I. (2003). Infecções do trato respiratório: principais agentes bacterianos e padrões de resistência: dados brasileiros do estudo internacional PROTEKT. @ rquivos de Otorrinolaringologia, 7(2), 97-107.

Moimaz, S. A. S., Amaral, M. A., Miotto, A. M. M., Costa, I. C. C., \& Garbin, C. A. S. (2016). Análise qualitativa do aleitamento materno com o uso do software IRAMUTEQ. Saúde e Pesquisa, 9(3), 567-577. https://doi.org/10.17765/2176-9206.2016v9n3p567-577

Mucha, A. M., Lohmann, P. M., Laste, G., \& Marchese, C. (2020). Orientation of breastfeeding in hospital high: an integrative review. Research, Society and Development, 9(7), e219974119. https://doi.org/10.33448/rsd-v9i7.4119

Ngocho, J. S., Jonge, M. I., Minja, L. G. A., Mahande, M. J., Msuya, S. E., \& Mambaga, B. T. (2019). Modifiable risk factors for community acquired pneumonia in children under 5 years of age in resource poor settings: a case-control study. Tropical Medicine \& International Health, 24(4), 484-492. https://dx.doi.org/10.1111/tmi.13211

Oddy, W. H., Sly, P. D., de Klerk, N. H., Landau, L. I., Kendall, G. E., Holt, P. G., Stanley, F. (2003). Breast feeding and respiratory morbidity in infancy: a birth cohort study. Archives of Disease in Childhood, 88(3), 224-228. https://doi.org/10.1136/adc.88.3.224

Palmeira, P., \& Carneiro-Sampaio, M. (2016). Immunology of breast milk. Revista da Associação Médica Brasileira, 62(6), 584-593. https://doi.org/10.1590/1806-9282.62.06.584

Parker, E. M., O'Sullivan, B. P., Shea, J. C., Regan, M. M., \& Freedman, S. D. (2004). Survey of breast-feeding practices and outcomes in the cystic fibrosis population. Pediatric Pulmonology, 37(4), 362-367. https://doi.org/10.1002/ppul.10450

Payne, S., \& Quigley, M. (2017). Breastfeeding and infant hospitalisation: analysis of the UK 2010 Infant Feeding Survey. Maternal \& Child Nutrition, 13(1), e12263. https://doi.org/10.1111/mcn.12263

Penders, J., Thijs, C., Vink, C., Stelma, F. F., Snijders, B., Kummeling, I., van den Brandt, P. A., \& Stobberingh, E. E. (2006). Factors influencing the composition of the intestinal microbiota in early infancy. Pediatrics, 118(2), 511-521. https://doi.org/10.1542/peds.2005-2824

Petrechen, L. N., Zago, F. H., Sesso, M. L., Bertoldo, B. B., Silva, C. B., Azevedo, K. P., de Lima Pereira, S. A., Geraldo-Martins, V. R., Ferriani, V. P., \& Nogueira, R. D. (2015). Levels and complexity of IgA antibody against oral bacteria in samples of human colostrum. Immunobiology, 220(1), 142-146. https://doi.org/10.1016/j.imbio.2014.08.009

Rocha, N. B., Garbin, A. J. I., Garbin, C. A. S., \& Moimaz, S. A. S. (2010). O ato de amamentar: um estudo qualitativo. Physis: Revista de Saúde Coletiva, 20(4), 1293-1305. https://doi.org/10.1590/S0103-73312010000400012

Rocha, N. B., Garbin, A. J. I., Garbin, C. A. S., Saliba, O., \& Moimaz S. A. S. (2013). Estudo Longitudinal sobre a prática de aleitamento materno e fatores associados ao desmame precoce. Pesquisa Brasileira em Odontopediatria e Clínica Integrada, 13(4), 337-342. https://doi:10.4034/PBOCI.2013.134.06

Ruiz-Palacios, G. M., Calva, J. J., Pickering, L. K., Lopez-Vidal, Y., Volkow, P., Pezzarossi, H., \& West, M. S. (1990). Protection of breast-fed infants against Campylobacter diarrhea by antibodies in human milk. The Journal of Pediatrics, 116(5), 707-713. https://doi.org/10.1016/s0022-3476(05)82652-6

Sears, M. R., Greene, J. M., Willan, A. R., Taylor, D. R., Flannery, E. M., Cowan, J. O., Herbison, G. P., \& Poulton, R. (2002). Long-term relation between breastfeeding and development of atopy and asthma in children and young adults: a longitudinal study. Lancet, 360(9337), 901-907. https://doi.org/10.1016/S0140-6736(02)11025-7

Silva, B. de C. F., Barros, G. C., Silva, L. P. da, Nascimento, M. M. do, Preto, V. A., Pereira, S. de S., \& Silva, M. M. da. (2020). Amamentação: fator primordial para a preservação da saúde ambiental. Research, Society and Development , 9 (8), e857986554. https://doi.org/10.33448/rsd-v9i8.6554

Sousa Siqueira, L., Stabnow Santos, F., Gomes Nogueira Ferreira, A., Fernandes Oliveira, A.L., Costa Dutra, R., \& Santos Neto, M. (2020). A prática da amamentação entre mulheres que trabalham: uma revisão integrativa. Research, Society and Development, 9 (9), e800997778. https://doi.org/10.33448/rsdv9i9.7778

Sousa, F. L. L. de, Alves, R. S. S., Leite, A. C., Silva, M. P. B., Veras, C. A., Santos, R. C. A., Freitas, R. G., Silva, V. C. R. da, Sisconetto, A. T., Sucupira, K. S. M. B., Silva, L. A. C. da, Santos, S. F. dos, Sousa, S. L. F. de, Galdino, M. A. de M., Fernandes, M. dos S., Silva, D. M. da, Santos, J. R. F. de M., Alencar, V. P., \& Ferreira, B. R. (2021). Benefits of breastfeeding for women and newborns. Research, Society and Development, 10(2), e12710211208. https://doi.org/10.33448/rsd-v10i2.11208

Succi, R. C. M. (1998). Aleitamento materno e doenças infecciosas. In C. K. Farhat, E. S. Carvalho, L. H. F. R. Carvalho, \& R. C. M. Succi (Eds.), Infectologia pediátrica. (2nd ed., pp. 12-15). São Paulo: Atheneu.

Tazinya, A. A., Halle-Ekane, G. E., Mbuagbaw, L. T., Abanda, M., Atashili, J., \& Obama, M. T. (2018). Risk factors for acute respiratory infections in children under five years attending the Bamenda Regional Hospital in Cameroon. BMC Pulmonary Medicine, 18, 7. https://doi.org/10.1186/s12890-018-05797 
Research, Society and Development, v. 10, n. 4, e35110414178, 2021

(CC BY 4.0) | ISSN 2525-3409 | DOI: http://dx.doi.org/10.33448/rsd-v10i4.14178

Tromp, I., Kiefte-de Jong, J., Raat, H., Jaddoe, V., Franco, O., Hofman, A., de Jongste, J., \& Moll, H. (2017). Breastfeeding and the risk of respiratory tract infections after infancy: The Generation R Study. PloS One, 12, e0172763. https://doi.org/10.1371/journal.pone.0172763

Tyrstrup, M., Melander, E., Hedin, K., Beckman, A., \& Mölstad, S. (2017). Children with respiratory tract infections in Swedish primary care; prevalence of antibiotic resistance in common respiratory tract pathogens and relation to antibiotic consumption. BMC Infectious Diseases, 17, 603. https://doi.org/10.1186/s12879-017-2703-3

Wold, A. E., \& Adlerberth, I. (1998). Does breastfeeding affect the infant's immune responsiveness? Acta Paediatrica, 87(1), 19-22. https://doi.org/10.1111/j.1651-2227.1998.tb01378.x

World Health Organization (1988). Persistent diarrhea in children in developing countries: memorandum from a WHO meeting. Bulletin of the World Health Organization, 66(6), 709-717.

World Health Organization (2018). Antibiotic resistance. https://www.who.int/news-room/fact-sheets/detail/antibiotic-resistance

Wright, A. L., Holberg, C. J., Taussig, L. M., \& Martinez, F. D. (2001). Factors influencing the relation of infant feeding to asthma and recurrent wheeze in childhood. Thorax, 56(3), 192-197. https://doi.org/10.1136/thorax.56.3.192

Yamakawa, M., Yorifuji, T., Kato, T., Inoue, S., Tokinobu, A., Tsuda, T., \& Doi, H. (2015). Long-term effects of breastfeeding on children's hospitalization for respiratory tract infections and diarrhea in early childhood in Japan. Maternal and Child Health Journal, 19, 1956-1965. https://doi.org/10.1007/s10995015-1703-4

Zöllner, M. S., \& Jorge, A. O. (2003). Candida spp. occurrence in oral cavities of breastfeeding infants and in their mothers' mouths and breasts. Pesquisa Odontológica Brasileira, 17(2), 151-155. https://doi.org/10.1590/s1517-74912003000200010

Zuanazzi, D., Souto, R., Mattos, M. B., Zuanazzi, M. R., Tura, B. R., Sansone, C., \& Colombo, A. P. (2010). Prevalence of potential bacterial respiratory pathogens in the oral cavity of hospitalised individuals. Archives of Oral Biology, 55(1), 21-28. https://doi.org/10.1016/j.archoralbio.2009.10.005 